\title{
HUBUNGAN KESADARAN MEMBACA TERHADAP PRESTASI BELAJAR SISWA PADA MATA PELAJARAN PENDIDIKAN AGAMA ISLAM KELAS X DI SMA NEGERI 10 KOTA BOGOR
}

\author{
Resti. $\mathrm{A}^{1}$ Chodidjah. $\mathrm{M}^{2}$ \\ Salati. $\mathrm{A}^{3}$ \\ Universitas Ibn Khaldun Bogor \\ ${ }^{1}$ restyanggraini82@gmail.com \\ ${ }^{2}$ makarim.chodidjah@gmail.com \\ ${ }^{3}$ salatiasmahasanah@gmail.com
}

\begin{abstract}
Abstrak
Tujuan penelitian ini adalah untuk mengetahui hubungan kesadaran membaca terhadap prestasi belajar siswa pada mata pelajaran pendidikan agama islam kelas X di SMA Negeri 10 Kota Bogor. Penelitian ini menggunakan metode kuantitatif dengan teknik pengumpulan data dengan kuesioner (angket) dan wawancara. Teknik pengumpulan data dengan cara wawancara kepada guru dan siswa. Sedangkan untuk kuesioner diberikan kepada responden yang telah terpilih secara random. Kemudian data yang sudah didapatkan dianalisis secara kuantitatif menggunakan teknik korelasi menggunakan SPSS 20. Hasil penelitian mengenai Hubungan Kesadaran Membaca Terhadap Prestasi Belajar Siswa pada Mata Pelajaran Pendidikan Agama Islam Kelas X di SMA Negeri 10 Kota Bogor, menunjukkan bahwa ada hubungan yang signifikan antara kesadaran membaca terhadap prestasi belajar siswa dengan nilai 0,435 yang berada dikisaran angka 0,40-0,70 yang berarti berhubungan sedang.
\end{abstract}

Kata kunci: kesadaran membaca, mata pelajaran PAI, prestasi belajar.

\begin{abstract}
Abstrack
The purpose of this study wa to determine the relationship of reading awareness to student learning achievement in class $X$ islamic relegious education subjects in state high schools 10 Bogor. This study uses quantitative methods wits data collection techniques by means of interviews with teachers and students while for questionnaires given to respondents who have been randomly selected then the data that has been obtained is analyzed quantitatively using correlation techniques using SPSS 20. The results of research on the relationship of reading awareness to achievement student learning on the subject of islamic education in class X in public high school 10 in the city of Bogor, shows that there is a significant relationship between reading awareness of student learning achievement with a value of 0,435 which is in the range of 0.40-0.70 which means having a moderate relationship.
\end{abstract}

Keywords: awareness of reading, PAI subjects, learning achievement.

\section{PENDAHULUAN}

Secara harfiah, kesadaran sama artinya dengan mawas diri (awareness). Kesadaran juga bisa diartikan sebagai kondisi dimana seorang individu memiliki kendali penuh terhadap stimulus internal maupun stimulus eksternal. Namun, kesadaran juga mencakup dalam persepsi dan pemikiran yang samar-samar disadari oleh individu sehingga akhirnya perhatiannya terpusat. Kesadaran dapat dibagi menjadi dua macam, yaitu: Pertama, Kesadaran pasifadalah keadaan dimana seorang individu bersikap menerima segala stimulus yang diberikan pada saat itu, baik stimulus internal maupun eksternal. Kedua, Kesadaran aktif adalah kondisi dimana seseorang menitikberatkan pada inisiatif dan mencari dan dapat menyeleksi stimulus-stimulus yang diberikan. Membaca merupakan proses memperoleh informasi, kegiatan 
membaca buku memiliki nilai yang lebih dibandingkan dengan kegiatan lain, seperti menonton televisi, video, mendengarkan radio. Pertama, dengan membaca buku, kita dapat memperoleh informasi dengan sangat mudah dan murah, sedangkan media informasi yang lain mensyaratkan biaya yang lebih tinggi dari membaca buku. Kedua, menurut para pakar neurologi (ilmu sains-medis tentang otak), membaca merupakan sebuah proses yang kompleks, yang melibatkan segenap panca indera, serta merangsang aktifnya sel-sel otak, dan dendrit-dendrit yang terus membuat simpul-simpul baru pada otak seiring berjalannya aktivitas membaca.

Kalau kesadaran dan membaca digabungkan maka dapat diambil kesimpulan bahwa kesadaran membaca adalah adanya kesadaran dalam diri seseorang untuk mencari informasi dan menambah ilmu pengetahuannya dengan melalui membaca sehingga timbulnya kesadaran betapa sangat pentingnya membaca dalam kehidupan sehari-hari. Pengertian belajar menurut Gagne adalah merupakan kegiatan yang kompleks. Hasil belajar berupa kapabilitas. Setelah belajar orang memiliki keterampilan, pengetahuan, sikap, dan nilai. Dengan demikian, belajar adalah seperangkat proses kognitif yang mengubah sifat stimulasi lingkungan, melewati pengolahan informasi, menjadi kapabilitas baru.

Prestasi pada dasarnya adalah hasil yang diperoleh dari suatu aktivitas. Sedangkan belajar pada dasarnya adalah suatu proses yang mengakibatkan perubahan dalam diri individu, yakni perubahan tingkah laku. Dengan demikian, dapat diambil pengertian yang cukup sederhana mengenai hal ini. Prestasi belajar adalah hasil yang diperoleh berupa kesan-kesan yang mengakibatkan perubahan dalam diri individu sebagai hasil dari aktivitas dalam belajar dan sebuah hasil penilaian pendidikan tentang kemajuan siswa setelah melakukan aktivitas belajar. Ini berarti prestasi belajar tidak akan bisa diketahui tanpa dilakukan penilaian atas hasil aktivitas belajar siswa. Fungsi prestasi belajar bukan saja untuk mengetahui sejauh mana kemajuan siswa setelah menyelesaikan suatu aktivitas, tetapi yang lebih penting adalah sebagai alat untuk memotivasi setiap siswa agar lebih giat belajar, baik secara individu maupun kelompok.

Agama mengatur hubungan manusia dengan Tuhan Yang Maha Esa, hubungan manusia dengan manusia, hubungan manusia dengan alam, hubungan manusia dengan dirinya yang dapat menjamin keselarasan, keseimbangan, dan keserasian dalam hidup manusia, baik sebagai pribadi maupun sebagai anggota masyarakat dalam mencapai kemajuan lahiriyah dan kebahagiaan rohaniyah. Pendidikan agama merupakan bagian pendidikan yang amat penting yang berkenaan dengan aspek-aspek sikap dan nilai, antara lain akhlak dan keagamaan. Oleh karena itu pendidikan agama juga menjadi tanggung jawab keluarga, masyarakat dan pemerintah. Sedangkan Pendidikan Agama Islam menurut Ditbinpaisun adalah suatu usaha bimbingan dan asuhan terhadap anak didik agar nantinya setelah selesai dari pendidikan dapat memahami apa yang terkandung di dalam Islam secara keseluruhan, menghayati makna dan maksud serta tujuannya dan pada akhirnya dapat mengamalkannya serta menjadikan ajaran-ajaran agama Islam yang telah dianutnya itu sebagai pandangan hidupnya sehingga dapat mendatangkan keselamatan dunia dan akhiratnya kelak.

\section{METODE}

Penelitian yang digunakan adalah penelitian kuantitatif dengan bentuk korelasi yaitu penelitian dengan melihat hubungan antara kesadaran membaca terhadap prestasi belajar siswa pada mata pelajaran pendidikan agama islam. Sedangkan penelitian kuantitatif dapat diartikan sebagai penelitian yang menggunakan angka (numerical) dari hasil observasi dengan maksud untuk 
menjelaskan fenomena dari observasi. Penelitian ini dilakukan selama 3 bulan, dimulai maret sampai dengan mei 2019. Sumber data, siswa pada sekolah tersebut terdiri dari siswa kelas $\mathrm{X}$ tahun ajaran 2018/2019, dengan jumlah populasi sebanyak 326 yang terbagi menjadi 9 kelas. Teknik pegambilan sampel menggunakan random sampling. Teknik pengumpulan data dilakukan dengan cara: 1) Interview (wawancara), metode pengumpulan data yang menghendaki komunikasi langsung antara penyelidik dengan subjek atau responden, 2) Angket/kuesioner, untuk memperoleh data tentang kesadaran membaca siswa kelas $\mathrm{X}$ SMA Negeri 10 Kota Bogor, 3) Dokumentasi, berupa foto-foto yang diambil pada saat pengambilan data dan observasi.

Berdasarkan data yang ada yaitu mengenai hubungan kesadaran membaca terhadaap prestasi belajar siswa pada mata pelajaran Pendidikan Agama Islam kelas X di SMA Negeri 10 Kota Bogor, maka peneliti menggunakan teknik analisis kolerasi yang mendasarkan diri pada dua buah variabel. Adapun teknik kolerasinya dengan menggunakan kolerasi SPSS 20.

\section{HASIL DAN PEMBAHASAN}

\subsection{Uji Persyaratan Analisi}

Variabel kesadaran membaca terdiri dari 30 pernyataan yang diberikan kepada responden. Berdasarkan hasil uji coba instrumen dari 30 butir pernyataan terdapat 24 butir pernyataan yang vaid dan 6 butir pernyataan yang tidak valid. Uji normalitas Uji normalitas yaitu untuk mengetahui teknik analisis tersebut bisa dilaksanakan atau tidak dilaksanakan, maka dengan begitu hal tersebut bisa diujikan menggunakan uji normalitas. Untuk normalitas peneliti menggunakan SPSS 20.

Tabel.1

Hasil Uji Normalitas Variabel X (Kesadaran Membaca)

\begin{tabular}{|l|l|r|}
\hline \multicolumn{2}{|c|}{ One-Sample Kolmogorov-Smirnov Test } & \multicolumn{1}{|c|}{ Unstandardized Residual } \\
\hline \multicolumn{2}{|c|}{} & .0000000 \\
\hline $\mathrm{N}$ & Mean & 1.78367671 \\
\hline \multirow{2}{*}{ Normal Parameters ${ }^{\mathrm{a}, \mathrm{b}}$} & Std. Deviation & .140 \\
\hline & Absolute & .113 \\
\cline { 2 - 3 } & Positive & -.140 \\
\cline { 2 - 3 } Most Extreme Differences & Negative & .140 \\
& & $.006^{\mathrm{c}}$ \\
\hline Test Statistic & & \\
\hline Asymp. Sig. (2-tailed) & & \\
\hline
\end{tabular}

Dari tabel di atas menunjukan nilai tes statistik Kolmogrov-Smirnov adalah 0,006 lebih besar dari 0,05 sehingga dapat disimpulkan bahwa data yang digunakan berdistiribusi normal.

\subsection{Analisis Data}

Untuk mengetahui ada tidaknya hubungan kesadaran membaca terhadap prestasi belajar siswa pada mata pelajaran Pendidikan Agama Islam kelas X di SMA Negeri 10 Kota Bogor, maka teknik analisis data yang digunakan adalah teknik korelasi menggunakan SPSS 20. Adapun analisisnya sebagai berikut:

\section{Tabel.2}

Hasil Uji Korelasi Variabel X (Kesadaran Membaca)

\begin{tabular}{|l|l|c|}
\hline \multicolumn{3}{|c|}{ Correlations } \\
\hline & Kesadaran_membaca & Prestasi_belajar \\
\hline
\end{tabular}




\begin{tabular}{|l|l|r|r|}
\hline Kesadaran_membaca & Pearson Correlation & 1 & \\
\cline { 2 - 5 } & Sig. (2-tailed) & $.435^{* *}$ \\
\cline { 2 - 5 } & $\mathrm{N}$ & .000 \\
\hline Prestasi_belajar & Pearson Correlation & $.435^{* * *}$ & \\
& Sig. (2-tailed) & .000 & 64 \\
\cline { 2 - 5 } & $\mathrm{N}$ & 64 & 1 \\
\hline
\end{tabular}

**. Correlation is significant at the 0.01 level (2-tailed).

Berdasarkan output di atas dapat diketahui nilai korelasi antara Variabel $\mathrm{X}$ dan Variabel Y sebesar 0,435. Tanda bintang berjulah dua artinya signifikansi pada level 0,01. Nilai kolerasi positif artinya terjadi hubungan positif antara media sosial dengan interaksi sosial. Untuk pengujian signifikansi peneliti menggunakan uji dua sisi dengan tingkat signifikansi $a=5 \%$. Kriteria pengujiannya adalah Ho diterima jika signifikansi $>0,05$ dan Ho ditolak jika signifikansi $<0,05$. Nilai signifikansi dari output di atas adalah 0,000 kurang dari 0,05 maka dari itu Ho ditolak dan $\mathrm{Ha}$ diterima, artinya bahwa terdapat hubungan antara kesadaran membaca terhadap prestasi belajar siswa pada mata pelajaran Pendidikan Agama Islam kelas X di SMA Negeri 10 Kota Bogo

Kesadaran membaca siswa kelas X di SMA Negeri 10 Kota Bogor sudah berlangsung dengan baik karena sudah meningkatnya minat membaca siswa. Mayoritas siswa memanfaatkan fasilitasfasilitas yang ada di sekolah seperti bukubuku bacaan yang ada di perpustakaan sekolah dan mencari bahan bacaan dengan menggunakan hp atau membelinya di tokoh buku. Hal ini dapat dilihat dari hasil angket rata-rata persentase peserta didik yang menjawab setuju sebesar $53.5 \%$.

Penelitian ini dilaksanakan di SMA Negeri 10 Kota Bogor, yang beralamat di Jl.Pinang 1 No. 17. Curugmekar, Bogor Barat, Kota Bogor, Jawa Barat 16113 dengan jumlah responden sebanyak 64 orang. Instrumen dalam penelitian ini menggunakan kuesioner. Butir kuesioner yang valid sebanyak 24 dari 30 butir pernyataan. Nilai alpha untuk variabel kesadaran membaca $(\mathrm{X})$ yaitu 0,435 dan untuk variabel prestasi belajar siswa (Y) mengambil dari hasil nilai akhir siswa (Rapor) dengan rata-rata nilai diatas KKM. Hal ini berarti instrumen yang digunakan peneliti dalam mengumpulkan data dapat dipercaya atau reliabel sebagai alat pengumpul data. Berdasarkan syarat uji analisis data yang dilakukan dalam penelitian ini, menunjukkan bahwa data berasal dari kontribusi normal dengan nilai signifikan 0,006 .

Sementara prestasi belajar siswa pada mata pelajaran Pendidikan Agama Islam kelas $\mathrm{X}$ di SMA Negeri 10 Kota Bogor terdata dengan baik yaitu nilai diatas rata-rata (KKM) dengan nilai terendah 73 dan nilai tertinggi 83. Tingkat kesadaran membaca siswa sudah semakin membaik dengan cara memanfaatkan waktu untuk membaca buku dari pada menghabiskan waktu dengan hal-hal yang tidak bermanfaat sehingga hal tersebut berpengaruh terhadap prestasi belajar siswa. Hal ini dapat dilihat dari hasil tabel 4.25 dengan nilai persentase sebesar 59\%.

Berdasarkan hasil kedua penelitian di atas menjelaskan, bahwa hipotesis nol (Ho) ditolak, dan hipotesis alternatif (Ha) diterima, yang berarti terdapat hubungan positif yang signifikan antara kesadaran membaca (Variabel X) dengan prestasi belajar siswa (Variabel Y).

Artinya bahwa berdasarkan hasil analisis secara kuantitatif menggunakan teknik korelasi menggunakan SPSS 20 dapat diperoleh 0,435 Jika dilihat dari tabel interpretasi maka angka indeks korelasi yang diperoleh yaitu 0,435 ternyata terletak antara 0,40-0,70. Maka dari data tersebut hal ini menunjukkan ada hubungan yang sedang atau cukup antara Kesadaran Membaca dengan Prestasi Belajar Siswa. 


\section{KESIMPULAN}

Berdasarkan penelitian yang telah dilaksanakan mengenai kesadaran membaca dan hubungannya dengan prestasi belajar siswa pada mata pelajaran Pendidikan Agama Islam kelas X SMA Negeri 10 Kota Bogor diperoleh kesimpulan yaitu terdapat hubungan yang siginifikan antara kesadaran membaca dengan prestasi belajar siswa. Besar koefisien yang diperoleh yaitu 0,435 dan berada pada level sedang.

\section{DAFTAR PUSTAKA}

Harjanto, Bob, (2011) Merangsang \& Melejitkan Minat Baca Anak Anda, (Yogyakarta: Tangguh Karya, h 7.

Djamarah Bahri syaiful, (2017) Prestasi Belajar dan Kompetensi Guru,
(Surabaya: USAHA NASIONAL, , h 21-24

Daradjat, Zakiyah, (2017), Ilmu Pendidikan Islam, (Jakarta: PT Bumi Aksara, h 86-88.

Firdaus, M. Azis, (2016), Metode Penelitian Edisi 2, (Tangerang: Jelajah Nusah 46.

Siti Walhidayah Nr, Pengertian Kesadaran Manusia Menurut Para Ahli dalam Ilmu

Psikologi,http://hidayahnr18.blogspot. co.id/2016/12/pengertian-kesadaranmanusiamenurut.html?m=1. Diakses, 30-01-2019, 16:41 WIB.

Dimyati dan Mudjiono, (2012), Belajar dan Pembelajaran,(Jakarta: Rineka Cipta, h7-10. 